\title{
Pengaruh Scaffolding Konseptual dalam Pembelajaran Group Investigation Terhadap Prestasi Belajar Fisika Siswa SMA dengan Pengetahuan Awal Berbeda
}

\author{
Rindu Rahmatiah, Supriyono Koes H., Sentot Kusairi \\ Pascasarjana Program Studi Pendidikan Fisika. \\ Universitas Negeri Malang. \\ Malang, Indonesia. \\ Email : rindurahmatiah@gmail.com.
}

\begin{abstract}
The aim of this research is to find out the effect of conceptual scaffolding strategy in Group Investigation towards physics achievement of senior high school students with different prior knowledge levels. This research was quasi-experimental research with factorial design. The population of this research was all grade XI students of SMAN 2 Mataram. The sample of this research was choosen by a cluster random sampling technique, each class consisted of 39 and 38 students. The experimental group learned lessons by conceptual scaffolding strategy in Group Investigation while the control group learned lessons by Group Investigation. The students of each groups were divided into two category based on their prior knowledge, these were students with higher prior knowledge and students with lower prior knowledge. Two way analysis of varian (two way anova) was used as the data analysis technique. The result of this research are: 1) there is physics achievement difference between the students who learn lessons by conceptual scaffolding strategy in Group Investigation and the students who learn lessons by Group Investigation; 2) there is physics achievement difference between the students with different prior knowledge levels; and 3) there is no effect of interaction between the strategy and the student's prior knowledge toward physics achievement.
\end{abstract}

Keywords : conceptual scaffolding, group investigation, physics achievement, prior knowledge.

\section{Pendahuluan}

Belajar Fisika pada jenjang SMA bertujuan agar siswa mampu menguasai konsep-konsep Fisika dan saling keterkaitannya, serta mampu menggunakan metode ilmiah berlandaskan sikap ilmiah untuk memecahkan masalah-masalah yang dihadapinya ${ }^{[1]}$. Dengan belajar Fisika, siswa memperoleh bekal pengetahuan, keterampilan, dan sejumlah kemampuan lainnya untuk studi lanjut maupun untuk memasuki dunia kerja. Sangat disayangkan jika dalam proses pembelajaran Fisika di sekolah, banyak siswa yang malah merasa kesulitan untuk mempelajari Fisika. Kesulitan siswa dalam mempelajari Fisika disebabkan oleh materi Fisika yang padat dan tidak kontekstual ${ }^{[2]}$. Hal tersebut menyebabkan banyak siswa yang mencoba menghafalkan konsep-konsep dan rumus-rumus Fisika tanpa mendalami makna fisisnya ${ }^{[3]}$. Siswa hanya mampu menghitung kuantitas Fisika menggunakan rumus namun tidak memahami makna fisis di balik rumus tersebut. Akibatnya, siswa tidak memiliki pemahaman materi Fisika dengan cukup baik sehingga berdampak langsung pada capaian prestasi belajar Fisika siswa. Di Indonesia, prestasi belajar Fisika siswa SMA tercermin pada hasil Ujian Nasional (UN). Hasil UN mata pelajaran Fisika SMA/MA Negeri dan Swasta di Indonesia tahun 2010 memperoleh nilai rata-rata 7,90. Tahun 2011, nilai ini meningkat sedikit ( 0,19 poin) menjadi 8,09 . Namun pada tahun 2012, nilai ini turun cukup signifikan
(0,57 poin) menjadi 7,52 ${ }^{[4]}$. Hasil ini mengindikasikan bahwa prestasi belajar Fisika siswa SMA di Indonesia semakin mengalami penurunan. Oleh karena itu, permasalahan berupa kesulitan-kesulitan siswa dalam belajar Fisika harus segera dicarikan solusinya.

Dalam membelajarkan Fisika, guru harus berusaha meminimalisir kesulitan siswa dalam belajar dengan menciptakan situasi pembelajaran yang menarik bagi siswa. Salah satu upaya yang dapat dilakukan adalah dengan memilih strategi pembelajaran yang tepat. Scaffolding merupakan salah satu bentuk pendampingan (apprenticeship) kognitif yang dapat dipilih untuk meningkatkan belajar siswa. Scaffolding merupakan langkah yang tepat diambil untuk mengurangi derajat kebebasan dalam mengerjakan suatu tugas sehingga siswa dapat berkonsentrasi pada keterampilan yang dirasa sulit untuk dimiliki ${ }^{[5]}$. Secara esensi, scaffolding berupaya meningkatkan belajar melalui interaksi sosial dengan melibatkan negosiasi isi, pemahaman, dan kebutuhan belajar ${ }^{[6]}$. Secara teoretik, scaffolding akan meningkatkan kualitas proses pembelajaran Fisika yang pada saatnya akan meningkatkan prestasi belajar siswa. Beberapa keunggulan penggunaan scaffolding diantaranya dapat meningkatkan penyelidikan dan kinerja siswa ${ }^{[7]}$, menjaga siswa dari rasa gagal ${ }^{[8]}$, dan dapat menjembatani kesulitan siswa dalam belajar ${ }^{[9]}$.

Dari beberapa jenis scaffolding yang tersedia, scaffolding konseptual dipilih untuk digunakan pada 
penelitian ini. Scaffolding konseptual dinilai sesuai dengan karakteristik mata pelajaran Fisika yang di dalamnya siswa belajar memahami kaitan dan hubungan suatu jaringan pengetahuan yang terdiri dari beberapa konsep dasar ${ }^{[10]}$. Scaffolding konseptual yang tersedia saat ini juga terdapat dalam berbagai bentuk. Haniin dan Rashidah menggunakan strategi scaffolding konseptual dalam penelitiannya berupa bantuan dua soal pilihan ganda untuk menyelesaikan permasalahan sintesis Fisika ${ }^{[11,12]}$. Bentuk scaffolding konseptual yang digunakan mengacu pada bentuk yang dikemukakan oleh Lin, et al. ${ }^{[13]}$. Berbeda dengan penelitian ini, scaffolding konseptual yang digunakan berupa peta konsep yang merupakan representasi diagram nonlinear hubungan yang bermakna antara konsep-konsep. Bentuk scaffolding konseptual yang digunakan pada penelitian ini mengacu pada bentuk yang dikemukakan oleh Dicarlo ${ }^{[14]}$. Di samping itu peneliti juga memberikan bantuan rumus-rumus yang berkaitan dengan materi Fisika yang dipelajari siswa.

Pelaksanaan scaffolding dalam kelompok kecil di kelas dilakukan dengan pembelajaran kooperatif. Hal ini sesuai dengan teori belajar konstruktivisme Vygotski yang menekankan belajar dalam aspek lingkungan sosial. Interaksi siswa dengan lingkungan sosialnya di kelas memungkinkan siswa belajar secara kooperatif atau bersama-sama. Group Investigation (GI) merupakan salah satu jenis pembelajaran kooperatif yang didasarkan pada pengalaman (experienced based learning situation). GI menggabungkan pandangan proses sosial yang demokratik dengan penggunaan strategi ilmiah untuk membantu siswa mengkonstruksi pengetahuannya. Langkah-langkah strategi scaffolding konseptual dalam pembelajaran Group Investigation adalah: 1) mengidentifikasi topik yang akan diselidiki dan mengorganisasi siswa menjadi kelompok peneliti, 2) merencanakan penyelidikan dalam kelompok, 3) melaksanakan penyelidikan kelompok dengan menggunakan lembar kerja siswa (LKS) ber-scaffold, 4) merencanakan presentasi, 5) melaksanakan penyajian, serta 6) evaluasi dan penilaian.

Pelaksanaan strategi scaffolding konseptual dalam pembelajaran Group Investigation menempatkan siswa bekerja secara berkelompok dengan panduan LKS ber-scaffold konseptual. Siswa dikelompokkan secara heterogen berdasarkan jenis kelamin dan tingkat pengetahuan awal. Setiap kelompok siswa diberikan permasalahan untuk diselesaikan bersama teman-teman satu kelompoknya. Dalam kerja kelompok ini, pengetahuan awal siswa memegang peranan yang sangat penting karena merupakan salah satu faktor yang menentukan keberhasilan siswa dalam belajar ${ }^{[15]}$. Selain itu, pengetahuan awal siswa juga berpengaruh pada kinerja, hasil akademik, dan kecepatan menyelesaikan studi ${ }^{[16]}$. Faktor pengetahuan awal inilah yang kemudian membagi siswa menjadi dua, yaitu siswa dengan pengetahuan awal tinggi dan siswa dengan pengetahuan awal rendah. Siswa dengan pengetahuan awal tinggi berpeluang besar dapat menyelesaikan masalah dengan mengikuti scaffold konseptual pada LKS. Siswa dengan pengetahuan awal rendah akan menyelesaikan masalah dengan bantuan scaffold konseptual pada LKS ditambah dengan bantuan scaffolding siswa yang berpengetahuan awal tinggi. Diskusi sebagai bentuk interaksi antar anggota kelompok menyebabkan terjadinya pengkonstruksian pengetahuan secara bersama. Scaffolding semacam ini dapat menciptakan lingkungan belajar yang aktif, efektif, dan kondusif. Siswa dapat berkerjasama dengan teman sebaya dalam menyelesaikan masalah yang mungkin tidak dapat diselesaikannya ketika hanya bekerja sendiri ${ }^{[17]}$. Dengan demikian, scaffolding yang digunakan dapat menjembatani pengetahuan awal Fisika siswa yang masih rendah dengan pengetahuan yang baru, sehingga pada saatnya nanti siswa mampu mencapai prestasi belajar Fisika yang diharapkan.

Materi pokok Keseimbangan dan Dinamika Rotasi adalah salah satu materi Fisika yang belum banyak diteliti dalam penelitian bidang Fisika. Serapan hasil UN SMA tahun 2012 menunjukkan bahwa untuk kemampuan menentukan besaran fisis dinamika rotasi (torsi/momentum sudut/ momen inersia/titik berat) dan penerapannya berdasarkan Hukum II Newton dalam benda tegar, memperoleh nilai rata-rata nasional $74,24^{[4]}$. Pada tahun 2014 , nilai rata-rata tersebut turun menjadi 70,05. Hasil tersebut mengindikasikan bahwa masih banyak siswa yang lemah pada penguasaan materi pokok Keseimbangan dan Dinamika Rotasi. Oleh karenanya, materi pokok Keseimbangan dan Dinamika Rotasi dinilai layak untuk dibawa ke ranah penelitian. Di lain pihak, prestasi belajar merupakan capaian yang penting dalam mata pelajaran Fisika. Oleh karena itu, peneliti ingin mengkaji secara empirik apakah penggunaan strategi scaffolding konseptual dalam pembelajaran Group Investigation benar-benar mampu meningkatkan prestasi belajar Fisika untuk siswa dengan pengetahuan awal tinggi dan rendah.

\section{TINJAUAN PUSTAKA}

\section{A. Scaffolding Konseptual dalam Pembelajaran Group Investigation}

Scaffolding konseptual merupakan bantuan yang tepat untuk menciptakan asosiasi antara ide-ide dalam zona perkembangan proksimal (ZPD) siswa. Scaffolding konseptual sesuai dengan karakteristik mata pelajaran Fisika, karena belajar Fisika adalah belajar memahami kaitan dan hubungan suatu jaringan pengetahuan yang terdiri dari beberapa konsep dasar ${ }^{[10]}$. Scaffolding konseptual dapat mendukung proses berpikir siswa mengenai 
informasi, ide-ide, dan teori-teori dalam lingkungan belajar siswa ${ }^{[18]}$. Scaffolding konseptual dapat pula membantu fokus pemikiran siswa karena menyederhanakan konsep yang kompleks ${ }^{[19]}$. Scaffolding konseptual dalam pembelajaran Group Investigation adalah pembelajaran Group Investigation dengan penggunaan strategi scaffolding konseptual berupa lembar kerja siswa ber-scaffold konseptual. Pembelajaran terdiri dari enam tahapan yaitu: grouping, planning, investigation (menggunakan lembar kerja siswa ber-scaffold konseptual), organizing, presenting, dan evaluating. Beberapa hasil penelitian terdahulu mengenai keunggulan penggunaan scaffolding dalam pembelajaran Group Investigation diantaranya dapat memperkenalkan aspek penting dari masalah dan membantu siswa mengidentifikasi masalah serta hubungannya dengan informasi penting ${ }^{[20]}$, membantu siswa menyelesaikan masalah dengan baik ${ }^{[21]}$, serta dapat mengkonstruk pemahaman dan menghubungkan pengetahuan sebelumnya dengan pengetahuan baru $^{[22]}$.

\section{B. Prestasi Belajar}

Prestasi belajar merupakan perubahan kapasitas dan isi seseorang ${ }^{[23]}$ dalam aspek pengetahuan, keterampilan dan sikap, sebagai akibat dari proses belajar yang dilakukannya. Prestasi belajar dapat pula disebut sebagai bukti keberhasilan yang dicapai siswa setelah melaksanakan usaha-usaha belajar, yang merupakan hasil interaksi siswa dengan lingkungan belajarnya. Interaksi yang dimaksudkan dalam hal ini adalah proses pembelajaran Fisika yang di dalamnya terjadi proses penerimaan konsep atau materi Fisika oleh siswa. Apabila interaksi yang terjadi antara siswa dengan lingkungan belajarnya baik, maka siswa dapat mempersiapkan dirinya dengan lebih baik pula ketika mengikuti tes pada akhir proses belajar yang diikutinya. Oleh karena itu, lingkungan yang baik dan kesiapan yang baik dalam diri siswa sangat diperlukan untuk mencapai prestasi belajar yang diinginkan.

\section{Pengetahuan Awal}

Pengetahuan awal merupakan pengetahuan yang dimiliki siswa mengenai suatu konsep, sebelum benar-benar mempelajari konsep atau materi tersebut. Pengetahuan awal dapat diartikan semua pengetahuan yang telah dimiliki siswa ketika memasuki lingkungan belajar yang secara potensial relevan untuk memperoleh pengetahuan baru $^{[24]}$. Pengetahuan awal juga merupakan keseluruhan pengetahuan awal seseorang, termasuk pengetahuan eksplisit dan implisit, pengetahuan konseptual, dan metakognotif ${ }^{[25]}$. Pengetahuan awal yang dimiliki setiap siswa berbeda-beda. Individu-individu yang berbeda menyatakan informasi yang berbeda menurut cara mereka, serta menyajikan informasi secara berbeda pula dalam memori mereka berdasarkan pengalaman dan pengetahuan awalnya ${ }^{[26]}$.

Pengetahuan awal siswa berperan penting dalam belajar karena menunjang kemudahan siswa dalam menerima dan memahami suatu materi atau konsep baru dalam pembelajaran. Pengetahuan awal siswa berpengaruh terhadap kinerja, hasil akademik, dan kecepatan menyelesaikan studi ${ }^{[16]}$ serta menjadi salah satu faktor penentu keberhasilan siswa dalam belajar $^{[15]}$. Pengetahuan awal siswa berkorelasi positif dengan prestasi akademik yang diraih siswa. Penelitian mengenai pengaruh pengetahuan awal siswa terhadap prestasi akademiknya pada elaborasi selama diskusi kelompok kecil menunjukkan bahwa elaborasi terbukti membantu siswa dengan pengetahuan awal tinggi, tetapi berbahaya bagi siswa dengan pengetahuan awal rendah ${ }^{[27]}$. Siswa dengan pengetahuan awal tinggi dimungkinkan telah memiliki pengetahuan dasar yang berkaitan erat dengan konsep yang mereka temui setelah berdiskusi. Dalam hal ini, pengetahuan awal yang baik dapat memberikan bimbingan yang baik pula untuk pembelajaran lebih lanjut bagi diri sendiri.

\section{METODE PENELITIAN}

Penelitian ini berada pada jalur penelitian quasi experimentation. Rancangan penelitian yang dipilih adalah rancangan faktorial dua faktor. Dalam penelitian ini, kelompok eksperimen diberikan perlakuan strategi scaffolding konseptual dalam pembelajaran Group Investigation sedangkan kelompok kontrol diberikan perlakuan pembelajaran Group Investigation. Penelitian ini mengambil siswa kelas XI IPA SMAN 2 Mataram Tahun Ajaran 2015/2016 sebagai subyek penelitian. Sampel penelitian dipilih dengan teknik cluster random sampling sebanyak 2 dari 6 kelas yang ada, yang terdiri dari 39 dan 38 orang siswa. Instrumen pengukuran yang dikembangkan meliputi tes pengetahuan awal siswa dan tes prestasi belajar Fisika siswa. Untuk menganalisis data yang diperoleh dalam penelitian ini, digunakan teknik analisis deskriptif dan analisis varian (anava) dua jalur. Hasil wawancara beberapa siswa juga digunakan untuk mendalami analisis deskriptif. Analisis deskriptif dilakukan terhadap data deskriptif seperti nilai rerata, simpangan baku, varian, dan penyajian data dalam bentuk tabel. Sebelum dilakukan analisis data secara menyeluruh, terlebih dahulu dilakukan uji persyaratan analisis yang meliputi uji normalitas sebaran data dan uji homogenitas data.

\section{HASIL DAN PEMBAHASAN}

\section{A. Hasil}

Berdasarkan Tabel 1 dapat diketahui bahwa kelompok siswa yang belajar dengan strategi scaffolding konseptual dalam pembelajaran Group 
Investigation mencapai skor rerata prestasi belajar Fisika lebih tinggi, yakni 42,90. Dalam kelompok tersebut, siswa dengan pengetahuan awal tinggi mencapai skor rerata lebih tinggi $(47,42)$ dibandingkan siswa dengan pengetahuan awal rendah $(39,04)$. Sedangkan kelompok siswa yang belajar dengan pembelajaran Group Investigation mencapai skor rerata prestasi belajar Fisika lebih rendah, yakni 39,13. Dalam kelompok tersebut, siswa dengan pengetahuan awal tinggi mencapai skor rerata lebih tinggi $(41,34)$ dibandingkan siswa dengan pengetahuan awal rendah $(36,67)$.

Tabel 1. Rerata Skor Prestasi Belajar Fisika Siswa

\begin{tabular}{|cccrr|}
\hline Kelompok & Pengetahuan Awal & Mean & Std. Deviation & N \\
\hline Strategi scaffolding konseptual dalam & Tinggi & 47.4167 & 6.42452 & 18 \\
pembelajaran Group Investigation & Rendah & 39.0429 & 7.89339 & 21 \\
& Total & 42.9077 & 8.31519 & 39 \\
\hline Pembelajaran Group Investigation & Tinggi & 41.3450 & 6.24664 & 20 \\
& Rendah & 36.6722 & 8.24070 & 18 \\
& Total & 39.1316 & 7.53855 & 38 \\
\hline
\end{tabular}

Tabel 2. Hasil Anava Dua Jalur Prestasi Belajar Fisika Siswa (Tests of Between-Subjects Effects)

\begin{tabular}{|crrrrrrr|}
\hline Source & $\begin{array}{c}\text { Type III Sum } \\
\text { of Squares }\end{array}$ & \multicolumn{1}{c}{ df } & \multicolumn{1}{c}{$\begin{array}{c}\text { Mean } \\
\text { Square }\end{array}$} & \multicolumn{1}{c}{ F } & Sig. & $\begin{array}{c}\text { Partial Eta } \\
\text { Squared }\end{array}$ & $\begin{array}{c}\eta \\
\text { (eta) }\end{array}$ \\
\hline Corrected Model & $1160.928(\mathrm{a})$ & 3 & 386.976 & 7.350 & .000 & .232 & \\
Intercept & 129605.612 & 1 & 129605.612 & 2461.535 & .000 & .971 & \\
STR & 341.457 & 1 & 341.457 & 6.485 & .013 & .082 & .286 \\
PA & 815.471 & 1 & 815.471 & 15.488 & .000 & .175 & .418 \\
STR * PA & 65.624 & 1 & 65.624 & 1.246 & .268 & .017 & .130 \\
Error & 3843.622 & 73 & 52.652 & & & & \\
Total & 134720.500 & 77 & & & & & \\
Corrected Total & 5004.550 & 76 & & & & & \\
\hline
\end{tabular}

a R Squared $=.232$ (Adjusted R Squared $=.200$ )

Berdasarkan Tabel 2 dapat dijelaskan sebagai dalam pembelajaran Group Investigation dan berikut. Pertama, probabilitas nilai rasio F strategi pembelajaran (STR) adalah 0,013 ( $\mathrm{p}<0,05)$. Nilai eta pada kolom $\eta$ menunjukkan nilai 0,286 yang artinya strategi pembelajaran mempengaruhi prestasi belajar dengan kriteria pengaruh medium (menengah). Dengan demikian, keputusan pertama adalah "terdapat perbedaan prestasi belajar Fisika antara siswa yang belajar dengan strategi scaffolding konseptual dalam pembelajaran Group Investigation dan siswa yang belajar dengan pembelajaran Group Investigation". Kedua, probabilitas nilai rasio F pengaruh pengetahuan awal (PA) terhadap prestasi belajar Fisika sebesar $0,000(p<0,05)$. Nilai eta pada kolom $\eta$ menunjukkan nilai 0,418 yang artinya pengetahuan awal mempengaruhi prestasi belajar dengan kriteria pengaruh besar (kuat). Dengan demikian, keputusan kedua adalah "terdapat perbedaan prestasi belajar Fisika antara siswa dengan pengetahuan awal tinggi dan siswa dengan pengetahuan awal rendah". Ketiga, probabilitas nilai rasio $\mathrm{F}$ interaksi antara strategi dan pengetahuan awal (STR*PA) sebesar 0,268 (p>0,05). Nilai eta pada kolom $\eta$ menunjukkan nilai 0,130 yang artinya interaksi strategi pembelajaran dengan pengetahuan awal mempengaruhi prestasi belajar dengan kriteria pengaruh kecil (lemah). Dengan demikian, keputusan ketiga adalah "tidak terdapat pengaruh interaksi antara strategi pembelajaran (scaffolding konseptual pembelajaran Group Investigation) dan pengetahuan awal siswa terhadap prestasi belajar Fisika siswa". Artinya, tidak terdapat pengaruh interaksi antara strategi pembelajaran dan pengetahuan awal Fisika terhadap prestasi belajar Fisika siswa. Dengan kata lain, strategi pembelajaran tidak saling bergantung dengan pengetahuan awal.

\section{B. Pembahasan}

Hasil pertama pada penelitian ini adalah terdapat perbedaan prestasi belajar antara kelompok siswa yang belajar menggunakan strategi scaffolding konseptual dalam pembelajaran Group Investigation dan kelompok siswa yang belajar menggunakan pembelajaran Group Investigation. Kelompok perlakuan strategi scaffolding konseptual dalam pembelajaran Group Investigation memperoleh nilai rata-rata prestasi belajar yang lebih tinggi dibandingkan kelompok perlakuan pembelajaran Group Investigation. Hasil penelitian ini sejalan dengan hasil penelitian Rasyidah yang menyatakan bahwa ada perbedaan antara kelompok siswa yang diajar melalui pembelajaran scaffolding konseptual berbasis STAD dan STAD terhadap kemampuan menyelesaikan masalah sintesis Fisika $^{[12]}$. Rahayu juga mengungkapkan bahwa prestasi belajar Fisika siswa dengan scaffolding visual berbasis STAD lebih 
tinggi dibandingkan prestasi belajar Fisika siswa dengan pembelajaran STAD $^{[28]}$

Belajar Fisika adalah belajar memahami kaitan dan hubungan suatu jaringan pengetahuan yang terdiri dari beberapa konsep dasar ${ }^{[10]}$ sehingga scaffolding konseptual dianggap sesuai dengan karakteristik pelajaran Fisika. Hasil penelitian Candra mengungkapkan bahwa scaffolding dapat membantu siswa dalam mengembangkan model mental Fisika siswa $^{[29]}$. Dalam penelitian ini, strategi scaffolding konseptual dapat memudahkan siswa dalam menanamkan konsep di pikirannya menjadi lebih sistematis. Scaffolding konseptual berupa peta konsep dan rumus-rumus terkait materi Fisika yang disajikan di dalam lembar kerja siswa mampu mengarahkan dan menata alur pemikiran siswa dengan lebih baik, dimulai dari konsep dasar ke konsep baru yang ingin ditanamkan guru berkaitan dengan materi Fisika yang dipelajari. Hal ini sejalan dengan hasil penelitian Way \& Rowe yang menyatakan bahwa scaffolding konseptual dapat membantu fokus pemikiran siswa karena menyederhanakan konsep yang kompleks ${ }^{[19]}$. Berkaitan dengan zona perkembangan proksimal (ZPD) siswa, hasil penelitian menunjukkan bahwa scaffolding konseptual sangat bermanfaat dan tepat membantu siswa menciptakan asosiasi antara gagasan-gagasan dalam ZPD siswa. Hal ini sesuai dengan pernyataan Danilenko bahwa scaffolding konseptual dapat mendukung proses berpikir siswa mengenai informasi, ide-ide, dan teori-teori dalam lingkungan belajar siswa ${ }^{[18]}$. Isnawati dalam penelitiannya telah menyebar kuisioner tentang respon siswa terhadap implementasi teknik scaffolding dalam proses menulis, hasilnya adalah lebih dari tiga perempat siswa setuju bahwa teknik scaffolding membantu mereka mengorganisasikan ide dan kosa kata ${ }^{[30]}$. Penelitian Abadi juga mengungkapkan bahwa proses berpikir subjek dalam memecahkan masalah bersifat unik dan setelah dilakukan scaffolding, proses berpikir siswa berkembang sehingga dapat memecahkan masalah ${ }^{[31]}$.

Penggunaan strategi scaffolding konseptual dalam pembelajaran kooperatif, dalam hal ini pembelajaran Group Investigation, secara tidak langsung membimbing siswa dalam belajar. Bimbingan tersebut tidak hanya berasal dari scaffolding konseptual yang tersaji pada lembar kerja siswa, tetapi juga berasal dari teman-teman satu kelompok siswa dalam kelompok investigasi. Terbukti kelompok siswa yang belajar menggunakan menggunakan strategi scaffolding konseptual dalam pembelajaran Group Investigation mampu mencapai prestasi belajar yang lebih baik. Koes $H$. dalam penelitiannya membandingkan pembelajaran scaffolding kooperatif, scaffolding langsung, dan pembelajaran langsung pada matakuliah Fisika dasar ${ }^{[9]}$. Hasil penelitian Koes $H$. menunjukkan bahwa pembelajaran scaffolding kooperatif paling efektif meningkatkan prestasi belajar Fisika pada matakuliah Fisika dasar ${ }^{[9]}$. Hasil penelitian Haniin juga menemukan bahwa terdapat perbedaan kemampuan menyelesaikan masalah sintesis Fisika antara kelompok siswa yang belajar melalui pembelajaran TPS dengan scaffolding konseptual dan pembelajaran TPS ${ }^{[11]}$.

Hasil wawancara peneliti terhadap beberapa siswa yang belajar menggunakan strategi scaffolding konseptual dalam pembelajaran Group Investigation mengungkapkan bahwa sebagian besar siswa merasa terbantu dengan adanya scaffolding konseptual berupa peta konsep dan rumus-rumus yang ada pada lembar kerja siswa mereka. Sejalan dengan hasil wawancara ini, Isnawati dalam penlitiannya juga mengungkapkan bahwa teknik scaffolding membuat lebih dari separuh siswa merasa termotivasi dan menunjukkan ketertarikan dalam mengikuti aktifitas belajar $^{[30]}$. Pada wawancara dalam penelitian ini, seorang siswa mengatakan bahwa melalui scaffolding konseptual yang diberikan, ia dapat mengetahui konsep dan rumus yang berkaitan dengan masalah yang dihadapinya. Siswa lainnya mengungkapkan bahwa setelah melihat dan menganalisis peta konsep dan rumus-rumus yang ada di dalam lembar kerja siswa, ia mempunyai gambaran untuk menyelesaikan permasalahan yang dihadapi. Secara umum, saat dihadapkan pada persoalan Fisika terkait materi yang dipelajari, langkah-langkah yang dilakukan siswa adalah memahami persoalan tersebut sejenak, menelaah peta konsep dan rumus-rumus yang ada pada lembar kerja siswa, baru kemudian mengerjakan persoalan Fisika yang disajikan.

Memang tidak semua siswa memahami scaffolding konseptual berupa peta konsep dan rumus-rumus yang disajikan pada lembar kerja siswa. Salah seorang siswa dalam wawancaranya berpendapat bahwa ia memahami peta konsep dan rumus-rumus yang ada di dalam lembar kerja siswa dengan membacanya berulang-ulang baru kemudian mengerjakan permasalahan. Disinilah peran tutor sebaya dalam pembelajaran Group Investigation menjadi sangat penting. Siswa yang telah lebih dahulu memahami peta konsep dan rumus-rumus tersebut, dapat bertukar pikiran dengan siswa yang belum memahaminya. Tentunya proses ini berlangsung dalam satu kelompok investigasi siswa. Dari hasil wawancara siswa juga diketahui bahwa ketika siswa kesulitan memahami peta konsep atau rumus-rumus yang disajikan, ia bertanya kepada teman satu kelompoknya yang dianggapnya lebih paham. Dialog sebagai komunikasi yang terjadi dalam kelompok siswa membuat siswa memiliki peluang dan kebebasan untuk mengungkapkan pengertian, pemahaman, atau bahkan ketidaktahuannya mengenai materi Fisika yang 
sedang dipelajari. Interaksi seperti ini merupakan keunggulan dari pembelajaran kooperatif (berkelompok), yaitu Group Investigation dapat meningkatkan tingkat partisipasi dan interaksi siswa $^{[32]}$. Pada akhirnya, satu kelompok siswa akan memiliki pemahaman yang sama pada materi Fisika yang dipelajari.

Saat siswa dihadapkan pada persoalan Fisika yang mirip dengan materi Fisika yang dikerjakan dengan bantuan scaffolding konseptual sebelumnya, sedikit banyak siswa akan mengingat proses-proses belajar yang pernah dilakukan. Pernyataan ini dibuktikan oleh hasil rata-rata tes prestasi belajar kedua kelompok perlakuan. Kelompok siswa yang belajar menggunakan strategi scaffolding konseptual dalam pembelajaran Group Investigation memperoleh skor tes prestasi belajar lebih tinggi daripada kelompok siswa yang belajar menggunakan pembelajaran Group Investigation, bahkan dengan selisih rata-rata yang cukup baik. Siswa yang belajar menggunakan strategi scaffolding konseptual juga mampu mencapai skor maksimum dan skor minimum tes prestasi belajar yang lebih tinggi dibandingkan siswa yang belajar tanpa menggunakan strategi scaffolding konseptual. Temuan-temuan tersebut semakin menegaskan bahwa strategi scaffolding konseptual dalam pembelajaran Group Investigation sangat membantu siswa dalam mencapai prestasi belajar yang lebih baik. Jbeili mengungkapkan bahwa scaffolding dalam pembelajaran Group Investigation dapat memperkenalkan aspek penting dari masalah dan membantu siswa mengidentifikasi masalah dan hubungannya dengan informasi penting ${ }^{[20]}$. Martinez mengemukakan bahwa scaffolding dalam pembelajaran Group Investigation membantu siswa menyelesaikan masalah dengan baik ${ }^{[21]}$. Mevarech \& Fridkin semakin menguatkan hasil penelitian ini dengan menyatakan bahwa scaffolding dalam pembelajaran Group Investigation dapat mengkonstruk pemahaman siswa dan menghubungkan pengetahuan sebelumnya dengan pengetahuan baru ${ }^{[22]}$.

Hasil kedua pada penelitian ini adalah terdapat perbedaan prestasi belajar antara kelompok siswa yang mempunyai tingkat pengetahuan awal berbeda. Siswa dengan pengetahuan awal tinggi memperoleh nilai rata-rata prestasi belajar yang lebih tinggi dibandingkan siswa dengan pengetahuan awal rendah, baik untuk kelompok siswa yang belajar menggunakan strategi scaffolding konseptual dalam pembelajaran Group Investigation maupun untuk kelompok siswa yang belajar menggunakan pembelajaran Group Investigation. Hasil penelitian ini sejalan dengan hasil penelitian Amiroh yang menyatakan bahwa ada perbedaan prestasi belajar Fisika antara siswa berpengetahuan awal tinggi dan rendah $^{[33]}$. Haniin dan Suratman, keduanya juga mengungkapkan bahwa terdapat perbedaan kemampuan menyelesaikan masalah sintesis Fisika antara kelompok siswa yang mempunyai tingkat pengetahuan awal berbeda ${ }^{[11,34]}$.

Perbedaan tingkat pengetahuan awal siswa diduga kuat sebagai penyebab perbedaan kemampuan siswa dalam mengasimilasi suatu konsep baru dalam belajar. Albab menemukan bahwa terdapat perbedaan kemampuan berpikir tingkat tinggi antara kelompok siswa yang mempunyai tingkat kemampuan awal berbeda $^{[35]}$. Siswa dengan tingkat pengetahuan awal tinggi dapat memahami konsep atau materi baru secara lebih baik dan terarah dibandingkan siswa dengan tingkat pengetahuan awal rendah. Hasil kajian Floris, et al. mengenai pengaruh pengetahuan awal siswa terhadap prestasi akademiknya pada elaborasi selama diskusi kelompok kecil mengungkapkan bahwa elaborasi membantu bagi siswa dengan tingkat pengetahuan awal tinggi, namun berbahaya bagi siswa dengan tingkat pengetahuan awal rendah ${ }^{[27]}$. Siswa dengan tingkat pengetahuan awal tinggi dimungkinkan telah memiliki pengetahuan dasar yang berkaitan erat dengan konsep yang mereka temui setelah berdiskusi dalam kelompok investigasi, sehingga pondasi belajarnya menjadi lebih kuat. Dalam prosesnya, siswa dengan tingkat pengetahuan awal tinggi terbukti lebih unggul dalam memaknai konsep baru yang mereka pelajari. Mereka dapat lebih mudah mengintegrasikan konsep-konsep awal yang dimilikinya dengan konsep-konsep baru yang ditemui selama proses pembelajaran sehingga terbentuk konsep baru yang utuh. Dengan kata lain, pengetahuan awal yang baik dapat memberikan bimbingan yang baik pula untuk pembelajaran lebih lanjut bagi diri sendiri.

Dalam penelitian ini, siswa dengan pengetahuan awal tinggi mampu mencapai prestasi belajar yang lebih baik dibandingkan siswa dengan pengetahuan awal rendah, terlepas dari strategi pembelajaran yang digunakan. Hasil ini menyiratkan bahwa dengan mengabaikan jenis strategi pembelajaran yang diberikan kepada siswa, siswa berpengetahuan awal tinggi tetap berpotensi memiliki prestasi belajar yang lebih baik dibandingkan siswa berpengetahuan awal rendah. Hasil ini sejalan dengan hasil penelitian Chen dan Chuang yang mengungkapkan bahwa siswa dengan pengetahuan awal tinggi lebih baik dalam mencapai hasil prestasi belajar dibandingkan siswa dengan pengetahuan awal rendah terlepas dari jenis pengelompokannya ${ }^{[36]}$. Hailikari juga menyatakan bahwa pengetahuan awal berpengaruh terhadap kinerja, hasil akademik, dan kecepatan menyelesaikan studi ${ }^{[16]}$. Penelitian Chen dan Dweyer semakin menguatkan hasil penelitian ini, bahwa siswa berpengetahuan awal tinggi menunjukkan hasil yang lebih baik daripada siswa berpengetahuan awal rendah untuk semua jenis tes ${ }^{[37]}$. 
Keuntungan utama dari penggunaan desain faktorial dalam penelitian ini adalah dapat diketahui interaksi antara variabel-variabel penelitian. Dalam banyak kasus, hubungan interaksi variabel lebih menarik untuk diketahui daripada pengaruh utama variabel ${ }^{[38]}$. Hasil penelitian ini menunjukkan bahwa tidak terdapat pengaruh interaksi antara strategi pembelajaran (strategi scaffolding konseptual dalam pembelajaran Group Investigation dan pembelajaran Group Investigation) dan pengetahuan awal siswa terhadap prestasi belajar Fisika siswa. Suratman juga memperoleh hasil penelitian yang sama bahwa tidak ada pengaruh interaksi strategi pembelajaran (strategi scaffolding-konseptual berbasis Group Investigation dan strategi pembelajaran Group Investigation) dan pengetahuan awal terhadap kemampuan pemecahan masalah Fisika siswa ${ }^{[34]}$. Begitu pula dengan hasil penelitian Haniin yang berkesimpulan bahwa tidak ada pengaruh interaksi antara stategi pembelajaran (pembelajaran TPS dengan scaffolding konseptual dan pembelajaran TPS) dan pengetahuan awal terhadap kemampuan menyelesaikan masalah sintesis Fisika $^{[11]}$.

Untuk membahas pengaruh interaksi ini, diperlukan analisis terhadap dua hasil sebelumnya pada penelitian ini, yaitu: 1) terdapat pengaruh strategi scaffolding konseptual dalam pembelajaran Group Investigation terhadap prestasi belajar Fisika dan 2) terdapat pengaruh pengetahuan awal siswa terhadap prestasi belajar Fisika. Jika dicermati, temuan pertama dan kedua merupakan hasil yang sejalan satu sama lain, yaitu "terdapatnya pengaruh". Howell menyatakan bahwa jika dua variabel bebas berpengaruh paralel terhadap sebuah variabel terikat, maka pengaruh interaksi dua variabel bebas tersebut tidak terjadi ${ }^{[38]}$. Hasil ketiga pada penelitian ini mengindikasikan bahwa capaian prestasi belajar Fisika siswa, bukan berasal dari pengaruh interaksi antara strategi pembelajaran yang digunakan dengan pengetahuan awal yang dimiliki siswa. Dengan kata lain, strategi pembelajaran tidak saling bergantung dengan pengetahuan awal siswa untuk mempengaruhi prestasi belajar Fisika siswa. Berkaitan dengan strategi pembelajaran, siswa yang belajar menggunakan strategi scaffolding konseptual dalam pembelajaran Group Investigation memiliki capaian prestasi belajar yang lebih baik dibandingkan dengan siswa yang belajar menggunakan pembelajaran Group Investigation. Berkaitan dengan pengetahuan awal siswa, siswa dengan tingkat pengetahuan awal tinggi memiliki prestasi belajar yang lebih tinggi dibandingkan siswa dengan tingkat pengetahuan awal rendah. Berdasarkan kedua hal tersebut dapat dikemukakan bahwa prestasi belajar Fisika siswa bergantung pada strategi pembelajaran dan bergantung pula pada pengetahuan awal siswa, namun tidak bergantung pada interaksi antara keduanya (strategi pembelajaran dan variabel pengetahuan awal siswa). Hasil penelitian ini sejalan dengan hasil penelitian Amiroh yang menyatakan bahwa tidak ada pengaruh interaksi antara pembelajaran (menggunakan visual scaffolding berbasis TPS dan TPS) dan pengetahuan awal terhadap prestasi belajar Fisika siswa ${ }^{[33]}$. Rahayu juga menemukan hasil yang bersesuaian, yaitu tidak terdapat pengaruh interaksi antara pembelajaran scaffolding visual berbasis STAD dan pengetahuan awal terhadap prestasi belajar Fisika ${ }^{[28]}$.

Interaksi merupakan suatu kondisi dimana pengaruh dari satu variabel bebas bergantung pada tingkatan variabel bebas lain $^{[38]}$. Hasil interpretasi kekuatan hubungan (effect sizes) dalam penelitian ini menunjukkan bahwa: 1) kekuatan strategi pembelajaran dalam mempengaruhi prestasi belajar memperoleh kriteria menengah, 2) kekuatan tingkat pengetahuan awal siswa dalam mempengaruhi prestasi belajar memperoleh kriteria besar, dan 3) kekuatan interaksi strategi pembelajaran dengan pengetahuan awal siswa dalam mempengaruhi prestasi belajar memperoleh kriteria kecil (lemah). Howell menyatakan bahwa pengaruh interaksi dua variabel bebas terhadap sebuah variabel terikat tidak terjadi jika dua variabel bebas berpengaruh paralel terhadap sebuah variabel terikat tersebut ${ }^{[38]}$. Pernyataan tersebut dapat diartikan: jika variabel bebas dan variabel moderator masing-masing memberi pengaruh terhadap variabel terikat maka pengaruh interaksi variabel bebas dan variabel moderator terhadap variabel terikat menjadi lemah atau bahkan tidak terjadi. Dalam penelitian ini, karena variabel bebas (strategi pembelajaran) mempengaruhi variabel terikat (prestasi belajar) secara menengah (medium) dan variabel moderator (pengetahuan awal siswa) mempengaruhi variabel terikat (prestasi belajar) secara besar (kuat), maka interaksi variabel bebas (strategi pembelajaran) dengan variabel moderator (pengetahuan awal siswa) dalam mempengaruhi variabel terikat (prestasi belajar) menjadi berkekuatan lemah. Hasil ketiga pada penelitian ini sejalan dengan hasil penelitian Koes $\mathrm{H}$. yang menyatakan bahwa tidak ada pengaruh interaksi antara strategi pembelajaran dengan pengetahuan awal Fisika terhadap prestasi belajar mahasiswa ${ }^{[9]}$. Chen dan Chuang dalam penelitiannya juga menemukan bahwa tidak ada pengaruh interaksi antara strategi kolaboratif dan pengetahuan awal terhadap prestasi belajar ${ }^{[36]}$.

\section{PENUTUP}

Beberapa kesimpulan yang dapat dikemukakan adalah sebagai berikut. Pertama, terdapat perbedaan prestasi belajar kelompok siswa yang belajar menggunakan strategi scaffolding konseptual dalam pembelajaran Group Investigation dan kelompok siswa yang belajar menggunakan pembelajaran Group Investigation. Kelompok siswa yang belajar 
menggunakan strategi scaffolding konseptual dalam pembelajaran Group Investigation mencapai prestasi belajar yang lebih tinggi dibandingkan kelompok siswa yang belajar menggunakan pembelajaran Group Investigation. Kedua, terdapat perbedaan prestasi belajar antara kelompok siswa yang mempunyai tingkat pengetahuan awal berbeda. Siswa dengan pengetahuan awal tinggi mencapai prestasi belajar yang lebih baik dibandingkan siswa dengan tingkat pengetahuan awal rendah. Ketiga, tidak terdapat pengaruh interaksi antara strategi pembelajaran dan pengetahuan awal siswa terhadap prestasi belajar Fisika. Strategi pembelajaran tidak saling bergantung dengan pengetahuan awal siswa dalam mempengaruhi prestasi belajar Fisika siswa.

Saran yang dapat diberikan adalah sebagai berikut. Pertama, penting bagi guru untuk melaksanakan strategi scaffolding konseptual dalam pembelajaran Group Investigation untuk meningkatkan prestasi belajar Fisika siswa. Kedua, guru hendaknya mengukur pengetahuan awal untuk mengetahui karakteristik siswa sehingga dapat memilih dan menerapkan strategi scaffolding yang tepat untuk memperoleh proses dan hasil belajar yang lebih maksimal. Ketiga, peneliti selanjutnya hendaknya melakukan penelitian lanjutan terkait penggunaan strategi scaffolding konseptual dalam pembelajaran Group Investigation untuk materi Fisika yang lain.

\section{UCAPAN TERIMA KASIH}

Terima kasih kepada Tim Penelitian Pascasarjana Universitas Negeri Malang: Bapak Dr. Supriyono Koes H., M.Pd.,M.A., Bapak Dr. Wartono, M.Pd., dan Bapak Dr. Muhardjito, M.S.

\section{REFERENSI}

[1] Mundilarto. 2002. Kapita Selekta Pendidikan Fisika. Yogyakarta: FMIPA UNY.

[2] Samudra, G.B., Suastra, I.W., \& Suma, K. 2014. Permasalahan-Permasalahan yang Dihadapi Siswa SMA di Kota Singaraja dalam Mempelajari Fisika. Journal Program Pascasarjana Universitas Pendidikan Ganesha Program Studi IPA, Volume 4 Tahun 2014.

[3] Hammer, D. 1994. Epistemological Beliefs in Introductory Physics. Cognitive and Instruction, 12(2), 151-183.

[4] Balitbang, Kemendikbud. 2012. Laporan Hasil Ujian Nasional. (Online), (http://118.98.234.22/ sekretariat/hasilun/), diakses 19 Mei 2015.

[5] Bruner, J. S. 1978. The Role of Dialogue in Language Acquisition. In A. Sinclair, R. Jarvella \& W. J. M. Levelt (Eds.), The child's conception of language. New York: Springer-Verlag.

[6] Dennen, V.P. 2004. Cognitive Apprenticeship in Educational Practice: Research on Scaffolding,
Modeling, Mentoring, and Coaching as Instructional Strategies. Dalam D. H. Jonassen (Ed.). Handbook of Research on Educational Communications and Technology. Mahwah, New Jersey: Lawrence Erlbaum Associates.

[7] Simons, K.D. \& Klein, J.D. 2007. The Impact of Scaffolding and Student Achievement Levels in a Problem Based Learning Environment. Instructional Science, Volume 35, Issue 1, pp 4172.

[8] Bean, T. W. \& Stevens, L. P. 2002. Scaffolding Reflection for Preservice and Inservice Teachers. Reflective Practice, 3(2), 205 - 218.

[9] Koes H., S. 2013. Pengaruh Strategi ScaffoldingKooperatif dan Pengetahuan Awal terhadap Prestasi Belajar dan Sikap pada Matakuliah Fisika Dasar. Jurnal Pendidikan Humaniora. Volume 1, Nomor 1, Maret 2013, hal 70-80.

[10] Lindstrom, C. \& Sharma, M. D. 2009. Link Map and Map Meeting: Scaffolding Student Learning. Physical Review Special Topiks - Physics Education Research, 5, 0101002.

[11] Haniin, K. 2014. Pengaruh Pembelajaran TPS dengan Scaffolding Konseptual terhadap Kemampuan Menyelesaikan Masalah Sintesis Fisika Ditinjau dari Pengetahuan Awal Siswa Kelas XI IPA SMAN 3 Malang. Tesis Magister pada Pascasarjana Program Studi Pendidikan Fisika Universitas Negeri Malang: tidak diterbitkan.

[12] Rasyidah, U.H. 2014. Pengaruh Scaffolding Konseptual berbasis STAD terhadap Kemampuan Menyelesaikan Masalah Sintesis Fisika ditinjau dari Kemampuan Berpikir Kritis. Tesis Magister pada Pascasarjana Program Studi Pendidikan Fisika Universitas Negeri Malang: tidak diterbitkan.

[13] Lin, D., Reay, N., Lee, A. \& Bao, L. 2011. Exploring The Role of Conceptual Scaffolding in Solving Synthesis Problems. Physical Review Special Topiks - Physics Education Research, 7 (2), $1-11$.

[14] DiCarlo, S.E. 2006. Essay: Cell Biology Should be Taught as Science is Practised. Nature Reviews, Molecular Cell Biology, April 2006 Volume 7.

[15] Klein, J.D. \& Keller, J.M. 1990. Influence of Student Ability, Locus of Kontrol and Type of Instruction Kontrol on Performance and Confidence. Journal of Educational Research, 83 (3), 140-146.

[16] Hailikari, T. 2009. Assesing University Students' Prior Knowledge, Implications for Theory and 
Practice. Helsinki: University of Helsinki Departement of Education Research Report 227.

[17] Hammond J., \& Gibbons, P. 2005. Teacher's Voices 8: Explicitly Suporting Reading and Writing In The Classroom. Sydney: National Centre for English Language Teaching and Research Macquarie University.

[18] Danilenko, E.P. 2010. The Relationship of Scaffolding on Cognitive Load in An Online SelfRegulated Learning Environment. A Dissertation submitted to The Faculty of The Graduate School of The University of Minnesota.

[19] Way, J. \& Rowe, L. 2008. The Role of Scaffolding in The Design of Multimedia Learning Objects. ICME TSG 22 New Technologies in The Teaching and Learning of Mathematics. Broad Theme 3: Design of Technology fo The Learning and Teaching of Mathematics. Research oriented paper.

[20] Jbeili, I. 2012. The Effect of Cooperative Learning With Metacognitive Scaffolding on Mathematics Conceptual Understanding and Procedural Fluency. International Journal for Research in Education, 32: 45-71.

[21] Martinez, M.R.P. 2011. Clil and Cooperative Learning. Encuentro 20, pp: 109-118.

[22] Mevarech, Z. \& Fridkin, S. 2006. The Effects of Improve on Mathematical Knowledge, Mathematical Reasoning and Metacognition. Metacognition and Learning, I (1): 85-98.

[23] Pasaribu, I. L. \& Simandjuntak, B. 1983. Metode Belajar dan Kesulitan Belajar. Bandung: Tarsito.

[24] Biemans, H.J.A. \& Siemons, P.R. 1996. CONTACT-2: A Computer Assited Insructional Strategy for Promoting Conceptual Change. Instructional Science, 24: 157-176.

[25] Dochy, F., Segers, M. \& Buchl M. 1999. The Relation Between Assesment Practices and Outcomes of Studies: The Case of Research on Prior Knowledge. Review of Educational Research, 69 (2): 147-188.

[26] $\mathrm{Hu}, \mathrm{D} .2006$. The Effect of Scaffolding on The Performance of Students in Computer - Based Concept Linking and Retention of Comprehension. Dessertation, Submitted to The Faculty of Virginia Polytechnic Institude and State University Blacksburg, Virginia.

[27] Floris, M., Blankenstein, V., Diana H., Dolmans, J.M., Cees P. M., Vleuten, V.d., Schmidt, H.G. 2013. Relevant Prior Knowledge Moderates The Effect of Elaboration During Small Group Discussion on Academic Achievement. Instructional Science, 41: 729-744.
[28] Rahayu, I. 2014. Pengaruh STAD Dengan Scaffolding Visual Terhadap Prestasi Belajar Fisika Pada Siswa Berpengetahuan Awal Berbeda. Tesis Magister pada Pascasarjana Program Studi Pendidikan Fisika Universitas Negeri Malang: tidak diterbitkan.

[29] Candra, S.N. 2013. Pengaruh Pembelajaran Inkuiri Terbimbing-Scaffolding terhadap Model Mental Fisika Ditinjau dari Kemampuan Pemecahan Masalah Siswa Kelas XI SMK. Tesis Magister pada Pascasarjana Program Studi Pendidikan Fisika Universitas Negeri Malang: tidak diterbitkan.

[30] Isnawati, U.M, 2009. Peningkatan Kemampuan Menulis Siswa Kelas 11 MA Hasyim Asy'ari Kembangbahu Lamongan melalui Penerapan Strategi Scaffolding. Tesis Magister pada Pascasarjana Program Studi Pendidikan Bahasa Inggris Universitas Negeri Malang: tidak diterbitkan.

[31] Abadi, M.Y.S. 2013. Proses Berpikir Siswa dalam Pemecahan Masalah Optimalisasi dengan Scaffolding. Tesis Magister pada Pascasarjana Program Studi Pendidikan Matematika Universitas Negeri Malang: tidak diterbitkan.

[32] Siddiqui, M.H. 2013. Group Investigation Model of Teaching :Enhancing Learning Level. Paripex - Indian Journal of Research, Volume 3 Issue 4.

[33] Amiroh, D. 2014. Pengaruh Visual Scaffolding Berbasis Think Pair Share Terhadap Prestasi Belajar Fisika Ditinjau dari Pengetahuan Awal Siswa SMAN 9 Malang. Tesis Magister pada Pascasarjana Program Studi Pendidikan Fisika Universitas Negeri Malang: tidak diterbitkan.

[34] Suratman. 2015. Pengaruh ScaffoldingKonseptual Berbasis Group Investigation terhadap Kemampuan Pemecahan Masalah Fisika Ditinjau dari Pengetahuan Awal Siswa Kelas XI SMA Plus Miftahul Ulum Sumenep. Tesis Magister pada Pascasarjana Program Studi Pendidikan Fisika Universitas Negeri Malang: tidak diterbitkan.

[35] Albab, A.F. 2015. Pengaruh E-Scaffolding dalam Think Pair Share Terhadap Kemampuan Berpikir Tingkat Tinggi Dinamika Partikel Pada Kemampuan Awal Berbeda Siswa di SMA. Tesis Magister pada Pascasarjana Program Studi Pendidikan Fisika Universitas Negeri Malang: tidak diterbitkan

[36] Chen, W.F. \& Chuang, C.P. 2011. Effect of Varied Types of Collaborative Learning Strategies on Young Children: An Experimental Study. International Journal of Instructional Media. (Online), dalam HighBeam Research. 
[37] Chen, W. \& Dwyer, F. 2006. Effect of Varied Elaborated Hypertext Strategies in Facilitating Students' Achievement of Different Learning Objectives. International Journal of Instructional Media. (Online), dalam HighBeam Research.

[38] Howell, D.C. 2011. Fundamental Statistics for Behavioral Sciences, Seventh Edition. Belmont, CA: Wadsworth, Cengage Learning.

\section{Biografi Penulis}

Rindu Rahmatiah, lahir di Ampenan, Lombok, pada tanggal 13 September 1991. Pada tahun 2013 telah menyelesaikan Sarjana Pendidikan dari Program Studi Pendidikan Fisika, Fakultas Keguruan dan Ilmu Pendidikan, Universitas Mataram. Saat ini sedang menempuh Pascasarjana pada Program Studi Pendidikan Fisika di Universitas Negeri Malang. Penelitian untuk tesis yang sedang dilakukan saat ini berkaitan dengan pengaruh strategi scaffolding konseptual dalam pembelajaran Group Investigation terhadap keterampilan proses sains dan prestasi belajar Fisika siswa SMA dengan pengetahuan awal berbeda. 